\title{
The role of educational diversity in investor relations
}

\author{
Arvid O.I. Hoffmann, Aida Tutic and Simone Wies \\ School of Business and Economics, Maastricht University, \\ Maastricht, The Netherlands
}

\begin{abstract}
Purpose - The purpose of this paper is to show the role of educational diversity in improving investor relations (IR) quality and examine how this impacts the number of shareholder activism incidents a firm encounters.

Design/methodology/approach - The paper reviews literature on marketing, finance, and corporate communications to develop a conceptual framework which is tested using a combination of secondary data and primary data collected through a survey amongst IR professionals working at companies in the Euronext 100 stock index.

Findings - The empirical results support the conceptual framework, showing higher IR quality levels and lower shareholder activism intensity for companies with educationally diverse IR teams. In particular, the presence of marketing and communication experts in IR teams contributes to higher IR quality and lower shareholder activism.

Research limitations/implications - Future research may investigate the robustness of the results with larger and internationally diversified samples and examine how, besides educational diversity, other organizational arrangements through which finance professionals work together with marketing and communication professionals impact IR quality.

Practical implications - The results suggest that to improve their IR quality and minimize shareholder activism, companies should check and when necessary increase the educational diversity of their IR teams.

Originality/value - This is the first paper investigating the role of educational diversity on IR quality and the impact on shareholder activism, developing and testing an innovative conceptual framework that integrates marketing, finance, and corporate communication theory.
\end{abstract}

Keywords Investors, Shareholders, Corporate communications, Investor relations, Educational diversity, Marketing-finance interface, Shareholder activism

Paper type Research paper

\section{Introduction}

Investor relations is the most necessary, superficial, overdue, controversial, valuable, time-consuming, and under-exploited part of today's management (Ryder and Regester, 1988, p. 5).

Originally, the prime role of investor relations (IR) was to disclose financial information to enable the firm's (prospective) shareholders to determine the market value of its securities (Savage, 1970; Marston, 1996). However, with a changing environment the importance and roles of IR have changed. A modern interpretation of IR includes marketing and communication concepts (Ryder and Regester, 1988; Rao and Sivakumar, 1999; Dolphin, 2004; Laskin, 2009) and assigns functions to it beyond financial disclosure. Accordingly, the main objective of IR is to establish a mutually beneficial relationship between the management of a company and its shareholders which is characterized by two-way symmetrical communication and not only governed by monetary factors (Kelly et al., 2010).
311

Received January 2011

Revised January 2011

Accepted May 2011

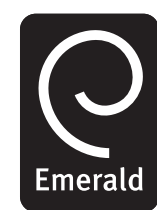

Corporate Communications: An International Journal

Vol. 16 No. 4, 2011 pp. $311-327$

(c) Emerald Group Publishing Limited $1356-3289$ DOI 10.1108/13563281111186959 
CCIJ

16,4

312

Although communication and relationship management are popular topics in marketing (Morgan and Hunt, 1994; Berry, 1995), and emerge in accounting as well (Lang and Lundholm, 1996; Botosan, 1997), finance has so far failed to focus on these concepts. In IR literature the power of communication and relationship management only recently gains momentum (Tuominen, 1997; Dolphin, 2004; Rao and Sivakumar, 1999; Hoffmann et al., 2011). In practice, however, IR is not yet acknowledged on a strategic level nor is the beneficial contribution of marketing and communication concepts to IR.

The costs of a contrarily loose relationship characterized by sparse communication are shareholders missing trust and satisfaction which makes a company's performance vulnerable to investors' temper. Lacking corporate transparency and explanatory power vis-à-vis the shareholders may induce them to challenge management in proxy contests or to pull out their assets, thus draining liquidity. As Kitchen (2000, p. 22) notes, "the market may forgive failure to meet a target, but the reputation of a company that is not open with its investors will never recover".

This paper empirically examines whether successful IR practice can translate into higher shareholder satisfaction and compliance. In particular, it assesses if diversity in the educational background of investor relation officers (IROs) influences IR quality and, in turn, shareholder satisfaction by less shareholder activism incidents. In line with recent literature, it is argued that educational diverse IR teams including both marketing and finance professionals translate into higher IR quality and less shareholder activism.

The paper sets off with a literature review on the different concepts related to IR. Based on the literature discussion, the hypotheses are developed, positioned in a conceptual framework and tested in an empirical study. Finally, the research is concluded and its limitations are discussed.

\section{Literature review}

\section{The IR function}

The initial role of IR as part of the finance function was to disclose relevant information to enable members of the financial community to determine the fair market value of the company's securities (Savage, 1970). The last decades, however, saw a rising emphasis on broadening this definition and deliberately managing IR. Rao and Sivakumar (1999) show that, particularly in the USA, IR departments are rapidly diffusing, apart from technical reasons, such as variability in performance, a growing number of institutional investors, and increasing organizational size, coercive and mimetic conditions were the primary drivers of this increased diffusion. In particular, anti-management resolutions brought forward by investor rights activists and financial analysts acting as shareholder watchdogs indirectly forced top management to signal commitment to shareholders, hence pushing the establishment of independent IR departments.

Originating from finance, it is not surprising that the most influential actors in IR still were finance and accounting departments. However, given the increasing focus on voluntary disclosure, public relations experts have entered the field and strengthen their influence therein (Hong and Ki, 2007). There is now no doubt that the field is a combination of different business topics (Petersen and Martin, 1996) and that a multidisciplinary approach considerably benefits the function. 
Hence, IR is nowadays defined as:

[...] a strategic management responsibility that integrates finance, communication, marketing and securities law compliance to enable the most effective two-way communication between a company, the financial community, and other constituencies, which ultimately contributes to a company's securities achieving fair valuation (NIRI, 2010).
Educational diversity

Communication matters, and in the light of current environmental conditions, it seems indispensable to turn it into a pivotal part of the IR function. Expanding equity markets, deregulation policies, global listings on foreign exchanges, as well as a global orientation of shareholder value creation have increased competitive pressures among capital acquirers. Also, the average company asset composition is nowadays tilted towards off-balance-sheet intangibles that are difficult to assess externally and require extensive corporate communication to be valued correctly by stock analysts and investors (Whitwell et al., 2007). Finally, shareholder activism and investor emancipation is gaining ground (Gillan and Starks, 2007), thereby questioning management conduct, and challenging the IR function as linkage between shareholders and companies. Likewise, behavioral finance research reveals that investors' decision making is not only anchored on financial performance, but is susceptible to psychological factors which can be influenced by communication (Shefrin, 2002).

Thus, current environmental developments as well as psychological factors imply a greater need to inform investors beyond traditional accounting statements to successfully convey the full potential of a firm's strategy and expected future returns. Successfully transmitting relevant information to the investor base is important and is critically dependent on IR practitioners possessing both strategic communication and public relations skills (Laskin, 2009). In particular, to build mutual understanding between a company and its investors, facilitating two-way communication and fostering a relationship perspective are essential (Kelly et al., 2010). For instance, shareholders are often seen as myopically interested in short-term gains, and consequently are often only approached with short-term financial arguments (Gneezy and Potters, 1997; Shefrin, 2002). However, this myopia might be due to uneducated investors to whom neither future strategies nor the implementation to reach prospective goals are adequately explained:

There are ample examples of companies which have successfully retained their shareholders' loyalty [...] throughout long product development cycles of profound downturns in their markets - if they have explained these issues clearly (Ryder and Regester, 1988, p. 7).

Hence, transparent communication and the management of informational asymmetries between shareholders and the company constitute areas on which IR can strongly support companies and posits IR as resource of both relational and intellectual weight.

\section{Educational diversity in IR}

A key factor in IR success is team construction. As touched upon before, the IR function is currently dominated by the finance profession (Laskin, 2009). This is at odds with both general literature arguing that team diversity contributes to performance (Cohen and Levinthal, 1990; Boeker, 1997; Bunderson and Sutcliffe, 2002; Jayne and Dipboye, 2004) and recent public relations research that argues that IROs need to broaden their skills set and be trained in both finance and communication 
CCIJ

16,4

314 to be able to successfully establish and manage long-term relationships with investors and other financial market participants (Kelly et al., 2010).

During the course of the last century, organizations experienced a transition towards complexity and specialization of managerial tasks (Richardson, 1972; Morrison and Adams, 1991). Although praised as enormous progress and development of the modern business (Wallerstein, 1974), specialization often implies losing sight of the bigger picture and the complex linkages between sub-functions (Ackoff, 1999). A consequence thereof is the need for a cross-functional perspective (Wind, 2005) and experiential diversity within the respective organizational function(s).

Diversity accumulates knowledge, promotes organizational effectiveness and efficiency, and thus, improves performance compared to homogeneous organizational work forms (O'reilly et al., 1989; Ancona and Caldwell, 1992; Jehn et al., 1999). Increased innovativeness (Bantel and Jackson, 1989), enhanced competitiveness (Hambrick et al., 1996) and quicker adoption of organizational change (Williams et al., 1995) are positive results of diverse teams, given that communication and knowledge sharing are assured.

Literature arguing in favour of diversity within IR teams origins from the late 1980s. Environmental factors as discussed in the general context of IR point out the importance of an enlarged horizon to conducting business, and the need of a multidisciplinary input to IR. As Laskin (2009, p. 210) elucidates, "investor relations is a practice on the border of finance and communications, and the synergy between these two areas is essential". Still, academic research on experiential and educational diversity in IR, in particular with regard to communication and marketing skills, is scarce and remains called for (Petersen and Martin, 1996; Laskin, 2009; Kelly et al., 2010).

Shareholder activism as the outcome of failing investor relationship management Shareholder activism and research thereof are recent phenomena, gradually swapping over from the USA to Europe (Smith, 1996; Black, 1998; Armour et al., 2003; Gillan and Starks, 2007; Hendry et al., 2007). Inherently, it is a failure of relationship management, stemming from the separation of a company's ownership and control. This in turn may lead to agency problems between the company's shareholders (principles) and managers (agents) (Jensen and Meckling, 1976; Fama, 1980; Gillan and Starks, 2007). To minimize agency problems, the board of directors is set up as a mediating and controlling entity. Shareholder activism becomes evident once the board is not acting on behalf of the shareholders, and shareholders feel a need to monitor, control and discipline the agents on their own.

The most common reason for shareholders to become active is to pressure management of poorly performing companies to improve performance and to discipline, restructure, or replace corporate executive officers (Brav et al., 2008; Del Guercio et al., 2008; Klein and Zur, 2009). The main forms of activism are:

- selling shares or voting with one's feet ("exit"); and

- holding on to shares but voicing dissatisfaction ("voice").

The voice mechanism can be expressed as private engagement with the corporate board or management, press campaigns, shareholder resolutions, or voting at annual general meetings (AGMs) (Hirschman, 1970). A popular and relatively low-cost form of activism are "just vote no" campaigns, whereby activists convince their fellow shareholders to withhold votes towards a directors' (re-)election to communicate 
dissatisfaction with the firm's corporate governance (Del Guercio et al., 2008). Likewise, shareholders can individually express their discomfort by voting against resolutions brought forward by management during a general meeting.

Although there has been great interest in the influence of shareholder activism on company performance, empirical evidence is mixed. Literature documents inconsistent evidence on whether activism is successful as to change corporate strategy as well as whether proposed actions are value adding (Strickland et al., 1996; Del Guercio and Hawkins, 1999; Karpoff, 1999; Gillan and Starks, 2007; Becht et al., 2008). There is, however, consensus that shareholder activism is a costly undertaking for any company. The firm bears administration and organization costs, as well as potential stock price depreciation (Ikenberry and Lakonishok, 1993, Cziraki et al., 2010). Further indirect costs apply to reputational damage and reduced attractiveness among investors (Del Guercio and Hawkins, 1999; Del Guercio et al., 2008), as well as distractions from operating business. In brief, companies naturally aim to avoid shareholder activism. As a function, IR might help companies to reduce activism by bonding agents and principles, and providing transparent information about corporate strategy and long-term payoffs. This in turn stresses the need of well-functioning communication channels between shareholders and the company, enabled by IR.

\section{Conceptual framework and hypotheses}

The literature review suggests a pivotal role of IR within the company. As previously emphasized, IR should be built on two-way communication and seen as valuable relationship management tool. Figure 1 shows the conceptual framework. In line with the literature presented before, educational diversity of IROs is proposed to enrich IR quality. IR quality, in turn, is expected to reduce the number of shareholder activism incidents. In this framework, educational diversity is operationalized as a company's IROs having a diverse educational background as represented by a mixture of finance, economics, marketing and communication, and product specialists. IR quality is assessed by an index of IR practices compiled from companies' web sites. Shareholder activism level represents the number of proposals put to vote at the company's AGM that are supported by less than 90 percent of the shareholders.

Well-functioning IR impacts a company's stock market performance, and can create shareholder value. It is associated with a more accurate valuation of a company's securities (Farraghe et al., 1994; Botosan, 1997; Gelb, 2000), increased security trading volume and liquidity (Healy et al., 1999; Hong and Huang, 2005), and increased analyst following (Francis et al., 1998). Additionally, IR benefits are reflected in positively influenced corporate reputation and credibility in the financial marketplace (Ellis, 1985, Gibbins et al., 1990), facilitating fundraising, improving employee morale and recruiting efforts, and boosting sales while decreasing customer turnover (Ellis, 1985). In a similar fashion, IR can impact investor loyalty, which in turn is expected to reduce

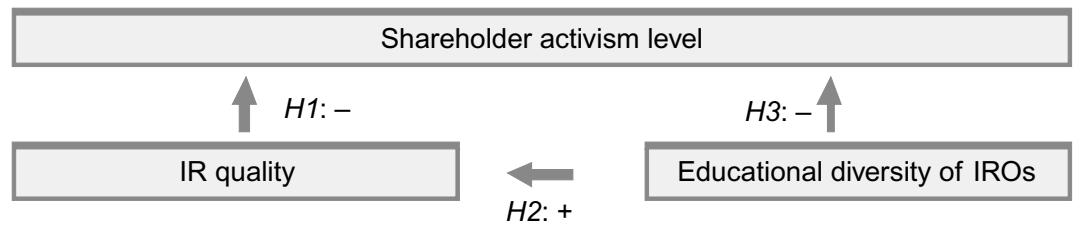

\section{Educational diversity}

315

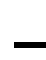


CCIJ

16,4

316 the risk of (hostile) takeovers and share price volatility, and decrease a myopic performance emphasis (Helm, 2007). The present paper aims to uncover a further result of good IR practice: reduced shareholder activism. As outlined before, IR provides possibilities to manage information and expectation asymmetries between companies and their shareholders, which is expected to reduce the probability of costly shareholder activism:

H1. IR quality is negatively related to the level of shareholder activism the company is exposed to.

Laskin (2009, p. 225) suggests that "both areas of expertise, business and communication, are essential to the practice of investor relations". As its tasks move away from mere financial reporting towards building long-term, mutually beneficial relationships that are characterized by two-way communication, there is a strong need of communication and marketing knowledge to be integrated into the hitherto financially dominated IR function. Educational diversity as reflected by a company's IROs being trained not only in finance, but also in, for example, marketing and communication is thus expected to positively influence a company's IR quality:

H2. A combination of different educational backgrounds in IR teams is positively related to the company's IR quality.

Finally, diverse professions merging in the IR function are expected to directly influence shareholder activism. The tangible form of IR work and associated information sharing might not capture all of the personal interaction and communication that is part of an educationally diverse IR practice. To the extent that being educated not only in finance, but also in marketing and communication, provides IROs with the relationship management skills that are necessary to engage in a two-way dialogue with investors (Kelly et al., 2010), educational diversity might also directly reduce shareholder activism:

H3. A combination of different educational backgrounds in IR teams is negatively related to the level of shareholder activism the company is exposed to.

\section{Research design and methodology \\ Data collection}

The research at hand analyses whether higher IR quality translates into lower shareholder activism, and if IR quality is influenced by the diversity of the IR team's educational background. The empirical investigation cannot rely entirely on publicly accessible data, and is thus complicated by data availability. The data collection focuses on companies included in the Euronext 100 stock index.

To measure IR quality, details on IR practices were retrieved through desk research by checking company web sites for IR activities. The IR activities classification was created in consensus to the internationally accepted IR criteria by the Belgian Association for Financial Analysts (ABAF, 2010). ABAF is an institution which annually awards IR practices of publicly held companies. The decision to use IR standards as suggested by ABAF was motivated by the widespread popularity and use of these award systems by European IR professionals. In order to ensure the completeness of the IR index that measures a company's IR quality, in-depth telephone 
interviews with field professionals (IROs and investors) were conducted. Table I summarizes the 21 IR practices on which the companies were screened. For every IR feature that a company had available on its corporate web site, it received a point, which where added up to come to an overall score of IR quality. In line with the ABAF index, this research categorizes IR practices as:

- operational information about a company;

- communication channels offered; and

- information disclosure width and depth.

Consistent with Laskin's (2009) findings, current IR practice is found to focus on responding to requests for information.

A data bottleneck pertains to the measurement of shareholder activism. In the USA, there are databases available which keep record of formally submitted shareholder resolutions, yet there is no comparable data source in Europe. For that reason, a different proxy of shareholder activism was used, namely the voting results at AGMs. Precisely, shareholder activism was determined to occur if any resolution put to vote was supported by less than 90 percent of the shareholders (Hoffmann et al., 2011). These data were collected by:

- reviewing the company web sites on voting results at AGMs; and

- requesting any missing voting outcomes via e-mail or telephone.

Finally, educational background data of all the IROs employed in a specific company was collected by direct request through e-mail or telephone.

\section{Sample characteristics}

Participants for which all data were successfully collected resulted in a sample of 41 out of the 100 companies that are part of the Euronext 100 stock index on May 1, 2010. In sum, the sample amounts to a total of $€ 738$ billion of stock outstanding which represented 24 percent of the total Euronext 100 stock index market capitalization at that time. The nationality of the companies varies with the majority being French $(n=22)$, followed by Dutch $(n=10)$, Belgian $(n=8)$ and one Portuguese company. The industries in which the companies operate are diverse, including consumer goods and services, base materials, technology, health care, oil and gas, telecommunications

\begin{tabular}{lll}
\hline Operational information & Communication channels & Information disclosure \\
\hline Company history & Link to IR on web site & Share price \\
Portfolio overview & Separation in audience & Share information \\
Mission statement & Mail & Declaration of dividends \\
& Phone & Navigation comfort \\
& News releases & Pages of annual report \\
& Analysts coverage & Conference calls \\
& Events & Details about executives \\
& & Executive compensation \\
& & Proxy reports \\
& & Information about AGMs \\
& & Webcast of AGM
\end{tabular}

\title{
Educational diversity
}

317

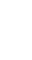

\author{
(1)
}

(1)

\author{
(1)
}


CCIJ

16,4

318

and the financial sector. All of those are equally represented implying that the sample is not biased towards one particular industry.

\section{Descriptive statistics of shareholder activism variable}

The study comprises a total of 3,021 resolutions put to vote during the period of 2005 until 2009. Totally, 452 of those were supported by less than 90 percent of the shareholders, and are thus eligible to be included in the final sample. Figure 2 shows an overview of the distribution of resolutions brought forward.

As shown in Figure 2, shareholder activism expressed in low voting support climaxes in topics related to the governance of stockholders' equity and board and committee issues. Topics addressed mainly dealt with trading company's shares, issuance of capital, dividend declarations, the nomination of directors, renewal of a director's mandate, or increasing the board's independence.

\section{Descriptive statistics of background variables and IROs educational diversity}

The findings show that 31 companies (76 percent) manage IR through a department structure and ten (24 percent) through an IR team embedded in another business function. Of the 31 companies which have an IR department in place, 43 percent devote an independent function to the management of IR, while 50 percent of the companies organize IR as a department subordinated to the finance department. Thus, even if there was a separate IR function in place most of the companies understand it as a sub-function underlying financial activities. Only three companies position IR in the public relations department. The educational background of IROs varies. As Figure 3 shows, financial experts still dominate the IR function, with 98 percent of the companies employing at least one IRO with a financially oriented educational background. Thus, in line with the literature review, marketing and communication skills remain to be underrepresented within the IR function (Ryder and Regester, 1988; Laskin, 2009).

Figure 2.

Distribution of shareholder activism topics

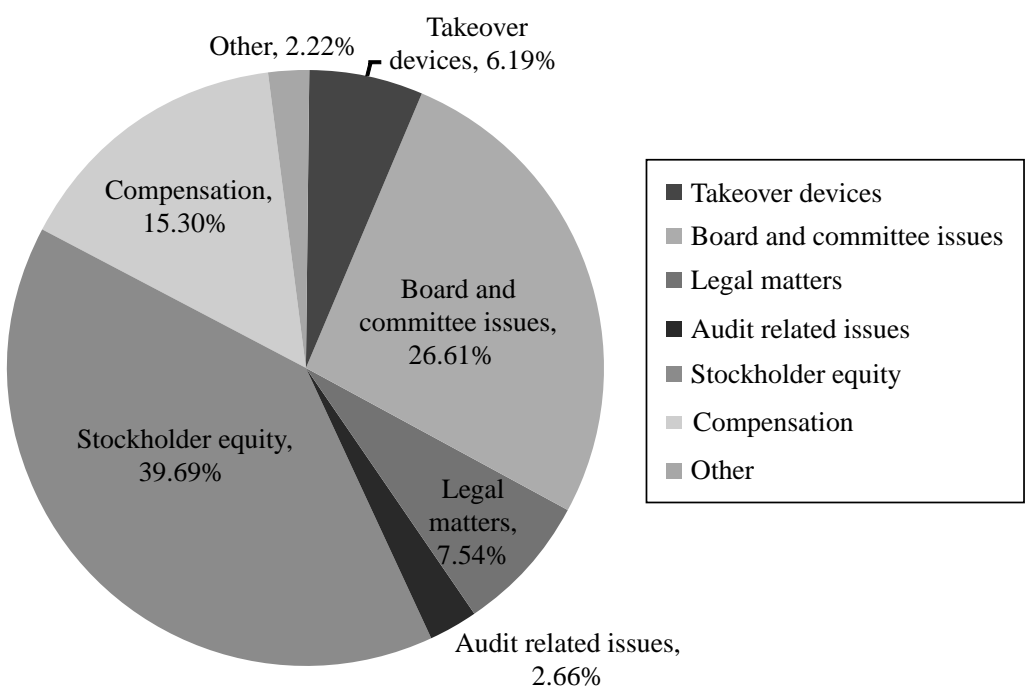




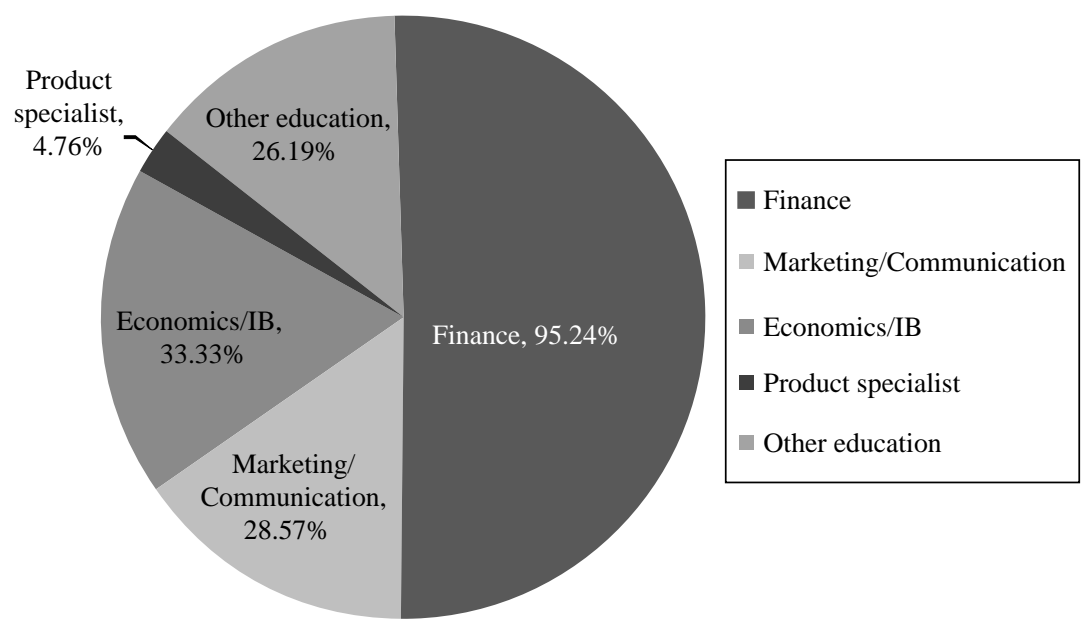

Notes: As IR departments typically consist of several IROs, each with different and/or multiple educational backgrounds, the numbers in this figure add up to more than 100 percent; as the surveyed IROs used these terms interchangeably to refer to the same educational background, marketing and communication as well as economics and international business are in the same educational category

\section{Educational diversity}

319

Figure 3.

Distribution of IROs educational background

\section{Results}

Effects of IR quality on shareholder activism

$H 1$ states that IR quality, measured by the number of IR features offered on a company's web site, is negatively related to the level of shareholder activism, proxied by voting results at the AGM. Classifying the subjects into three groups based on their IR quality (i.e. high, medium, and low IR quality) allows for an ANOVA of possible dissimilarities in shareholder activism levels. Table II documents the ANOVA results, showing that indeed there is a statistically significant difference in the mean level of shareholder activism across the groups $(F=7.31, p=0.002)$. Companies with high IR quality levels recorded the lowest shareholder activism scores and companies with low IR quality levels the highest. To check whether the difference exists between all three IR groups, we conduct a post hoc comparison exploring mean differences between each of the IR quality groups. The post hoc results in Table II show that there are statistically significant mean differences of 14.02 between low and high IR quality groups $(p=0.002)$ and of 9.4 between medium and high IR quality groups $(p=0.029)$. There is no statistically significant difference between low and medium IR quality groups ( $p=0.457)$. Hence, IR best practice seems to have an exceptionally high payoff with regard to reduced shareholder activism incidents. To check whether these effects are indeed driven by differences in IR quality, we examine whether the IR quality groups differ regarding their companies' headquarter location, market capitalization, and industry. No significant differences regarding these control variables were found.

Next, the ANOVA is complemented by a linear regression analysis, regressing the level of IR quality on the number of shareholder activism incidents a firm encounters. In line with the former results, the regression results in Table III document a significantly negative relationship between shareholder activism and IR quality. 


\section{CCIJ \\ 16,4}

320

\begin{tabular}{l}
\hline \\
\hline Shareholder activism (mean) \\
Shareholder activism (SD) \\
Difference to low IR quality \\
$p$-value \\
Difference to medium IR quality \\
$p$-value \\
Difference to high IR quality \\
$p$-value \\
$n$
\end{tabular}

Low IR quality

17.82
11.873

-4.618
0.457
$-14.018^{* * *}$
0.002
11

Notes: Significant at: ${ }^{*} 10,{ }^{* *} 5,{ }^{* *} 1$ percent levels; this table represents the ANOVA results of IR quality on shareholder activism $(F=7.311, p=0.002)$; shareholder activism is the dependent variable; IR quality is measured by the number of IR features available on a company's web site and shareholder activism is measured by the number of resolutions which received less than 90 percent of shareholder votes during former annual general shareholder meetings; the group high IR quality exhibits good practice with 18-20 (maximum) IR activities, medium IR quality offers up to 17, and low IR quality up to 15 IR activities; SD - standard deviation
Table II.

Shareholder activism levels for different levels of IR quality
Table III.

The impact of IR quality on shareholder activism

\begin{tabular}{|c|c|c|}
\hline & \multicolumn{2}{|c|}{ Shareholder activism } \\
\hline & Coefficients & Standardized coefficients \\
\hline $\begin{array}{l}\text { Constant } \\
\text { IR quality } \\
n \\
\text { Adjusted } R^{2} \\
F \text {-value }\end{array}$ & $\begin{array}{l}50.8^{* * * *}(3.77) \\
-2.39 * * *(-2.974) \\
41 \\
0.164 \\
8.84 * *\end{array}$ & $-0.43^{* * *}(-2.974)$ \\
\hline \multicolumn{3}{|c|}{$\begin{array}{l}\text { Notes: Significant at: }{ }^{*} 10,{ }^{* *} 5,{ }^{* * *} 1 \text { percent levels; this table represents linear regression results of } \\
\text { IR quality on shareholder activism; shareholder activism is the dependent variable; for each coefficient, } \\
\text { the unstandardized coefficient, the standardized coefficient and the } t \text {-statistics (in parentheses) are } \\
\text { reported; IR quality is measured by the number of IR features available on a company's web site and } \\
\text { shareholder activism is measured by the number of shareholder resolutions which received less than } \\
90 \text { percent of shareholder votes during former annual general shareholder meetings }\end{array}$} \\
\hline
\end{tabular}

Notably, increasing IR quality by adding one additional online IR feature reduces the mean number of shareholder activism incidents by 2.39. The empirical results thus support $H 1$ as there is a negative relationship between shareholder activism and IR quality.

\section{Effects of educational diversity on IR quality and shareholder activism}

The next step of the analysis pertains to the effect of educational diversity in IR teams on IR quality and shareholder activism levels. For this, an ANOVA was conducted based on four groups with increasing educational diversity, ranging from group 1 with one form of profession in the IR team to group 4 with four different professions. Table IV reveals that these groups differ significantly and as expected $(F=2.313$, $p=0.092$ ). The findings confirm our conjecture that a diverse educational background of IROs is positively associated with a company's IR quality. Again, we check whether 


\begin{tabular}{|c|c|c|c|c|c|}
\hline & $\begin{array}{c}\text { Educational } \\
\text { diversity } 1\end{array}$ & $\begin{array}{c}\text { Educational } \\
\text { diversity } 2\end{array}$ & $\begin{array}{c}\text { Educational } \\
\text { diversity } 3\end{array}$ & $\begin{array}{c}\text { Educational } \\
\text { diversity } 4\end{array}$ & $\begin{array}{l}\text { diversity } \\
\text { divalual }\end{array}$ \\
\hline $\begin{array}{l}\text { IR quality } \\
\text { (mean) } \\
\text { IR quality (SD) } \\
n\end{array}$ & $\begin{array}{l}15.857 \\
1.167 \\
14\end{array}$ & $\begin{array}{l}15.471 \\
2.577 \\
17\end{array}$ & $\begin{array}{l}17.889 \\
1.054 \\
9\end{array}$ & $\begin{array}{l}18 \\
1.986 \\
1\end{array}$ & 321 \\
\hline \multicolumn{5}{|c|}{$\begin{array}{l}\text { Notes: Significant at: }{ }^{*} 10,{ }^{*} 5,{ }^{* * *} 1 \text { percent levels; this table represents the ANOVA results of } \\
\text { educational diversity on IR quality }(F=2.313, p=0.092) \text {; IR quality is the dependent variable; } \\
\text { IR quality is measured by the number of IR features available on a company's web site and educational } \\
\text { diversity is coded into four groups, where educational diversity } 1 \text { comprises companies which IR team } \\
\text { consists of merely one profession, educational diversity } 2 \text { includes companies which employ two } \\
\text { professions in their IR function, educational diversity } 3 \text { reveals three professions, and educational } \\
\text { diversity } 4 \text { four professions, respectively; SD - standard deviation; no post hoc test results reported as } \\
\text { educational diversity } 4 \text { has not enough observations to perform this test }\end{array}$} & $\begin{array}{r}\text { Table IV. } \\
\text { IR quality levels } \\
\text { for different levels } \\
\text { of educational } \\
\text { diversity in IR teams }\end{array}$ \\
\hline
\end{tabular}

these groups differ regarding a number of control variables (i.e. headquarter location, market capitalization, and industry), but find no significant differences between the different groups.

Separating the individual effects of different professional backgrounds is pursued by means of a regression analysis, taking educational expertise of IROs as independent dummy variables regressed on the level of IR quality. Finance is taken as the base profession (benchmark) against which the impact of other educational orientations on IR quality are measured. Table V shows that IR departments with a marketing or communication specialization record a higher IR quality and have on average 1.73 more online IR features than IR departments without those experts $(t=2.667, p=0.011)$. Compared to other professional groups, such as economics and product specialists,

\begin{tabular}{lcc}
\hline & Coefficients & $\begin{array}{c}\text { IR quality } \\
\text { Standardized coefficients }\end{array}$ \\
\hline Constant & $15.833^{* * *}$ & \\
Marketing and communication & $1.667^{* *}(2.667)$ & $0.387(2.667)$ \\
Economics and international business & $0.167(0.283)$ & $0.040(0.283)$ \\
Product specialist & $-1.667(-1.27)$ & $-0.183(-1.27)$ \\
Other education & $1.167^{*}(-1.824)$ & $0.264(-1.824)$ \\
$n$ & 41 & \\
Adjusted $R^{2}$ & $0.225 * *$ & \\
$F$-value & $3.907^{* *}$ &
\end{tabular}

Notes: Significant at: ${ }^{*} 10,{ }^{* *} 5,{ }^{* * *} 1$ percent levels; this table represents the multiple regression results of IR education on IR quality; IR quality is the dependent variable; for each coefficient, the unstandardized coefficient, the standardized coefficient, and the $t$-statistics (in parentheses) are reported; IR quality is measured by the number of IR features available on a company's web site and IR education is assessed through dummy variables; the dummy variables consist of marketing and communication, economics and international business, product specialist, and other education; the target dummy is equal to one if the corresponding firm has one IRO with matching educational background in place and zero otherwise; the base level used against which the other independent variables are benchmarked is finance

Table V.

The impact of IR education on IR quality 
CCIJ

16,4

322

marketing and communication experts are the only group that statistically contribute to a higher IR quality.

Hence, in line with $H 2$, companies that employ experts from various fields document an increased IR quality as measured by the number of IR activities offered on the company's web site. Having marketing or communication experts on the IR team significantly improves IR quality.

Finally, to test $H 3$, an ANOVA compares the four different groups as based on the number of different educational backgrounds in the IR team regarding these companies' shareholder activism levels. Table VI reveals that the groups differ significantly $(F=20.406, p=0.000)$. The group with four different educational backgrounds in the IR team did not reveal any shareholder activism while the group with merely one educational profession in their IR team record a mean score of 22.64, suggesting a negative relationship between the two variables. These explorative findings support the hypothesis that a diverse educational background negatively relates to shareholder activism intensity.

Again, to get a more precise picture of which educational background has the highest influence on shareholder activism a regression analysis was conducted. The four educational expertise dummies were regressed against the number of shareholder activism incidents. Here again, finance is taken as the benchmark against which the impact of other educational orientations on shareholder activism are measured. Table VII indicates that IR departments with a marketing or communication specialist record significantly lower numbers of shareholder activism $(t=-3.438, p=0.001)$, and similar effects are found for departments having economics and business experts. In line with the $H 3$, companies with an educationally diverse IR team suffer less from shareholder activism.

\section{Discussion and conclusion}

Corporate communications research increasingly recognizes that IR is an activity of key importance for publicly traded companies and might lead to a competitive advantage when executed well (Allen, 2002). Surprisingly, however, academic attention for this topic

\begin{tabular}{lcccc}
\hline & $\begin{array}{c}\text { Educational } \\
\text { diversity 1 }\end{array}$ & $\begin{array}{c}\text { Educational } \\
\text { diversity 2 }\end{array}$ & $\begin{array}{c}\text { Educational } \\
\text { diversity 3 }\end{array}$ & $\begin{array}{c}\text { Educational } \\
\text { diversity 4 }\end{array}$ \\
\hline $\begin{array}{l}\text { Shareholder activism } \\
\text { (mean) }\end{array}$ & 22.64 & 6.88 & 1.89 & 0 \\
$\begin{array}{l}\text { Shareholder activism } \\
\text { (SD) }\end{array}$ & 9.5 & 6.264 & 2.369 & 0 \\
$n$ & 14 & 17 & 9 & 1
\end{tabular}

Notes: Significant at: ${ }^{*} 10,{ }^{* *} 5,{ }^{* * *} 1$ percent levels; this table represents the ANOVA results of IR education on shareholder activism $(F=20.406, \quad p$-value $=0.000)$; shareholder activism is the dependent variable and stands for shareholder activism as measured by the number of resolutions which received less than 90 percent of shareholder votes during former annual general shareholder meetings; educational diversity is coded into four groups, where educational diversity 1 comprises companies which IR team consists of merely one profession, educational diversity 2 includes companies which employ two professions in their IR function, educational diversity 3 reveals three professions, and educational diversity 4 four professions; SD - standard deviation; no post hoc test results reported as educational diversity 4 has not enough observations to perform this test

\section{Table VI.}

Shareholder activism levels for different levels of educational diversity in IR teams 


\begin{tabular}{l}
\hline \\
\hline Constant \\
Marketing and communication \\
Economics and international business \\
Product specialist \\
Other education \\
$n$ \\
Adjusted $R^{2}$ \\
$F$-value
\end{tabular}

Notes: Significant at: ${ }^{*} 10,{ }^{* *} 5,{ }^{* * *} 1$ percent levels; this table represents the multiple regression results of IR education on shareholder activism; for each coefficient, the unstandardized coefficient, the standardized coefficient, and the $t$-statistics (in parentheses) are reported; shareholder activism is measured by the number of resolutions which received less than 90 percent of shareholder votes during former annual general shareholder meetings and IR education is assessed through dummy variables; the dummy variables consist of marketing and communication, economics and international business, product specialist, and other education; the target dummy is equal to one if the corresponding firm has one IRO with matching educational background in place and zero otherwise; the base level used against which the other independent variables are benchmarked is finance

\section{Educational diversity}

\author{
$19.732 * * *(10.902)$ \\ $-9.597 * * *(-3.438)$ \\ $-10.591^{* * *}(-4.033)$ \\ $-7.433(-1.268)$ \\ 41 \\ 0.503
}

$-0.399(-3.438)$

$-0.459(-4.033)$

$-0.146(-1.268)$

$-0.294(2.536)$

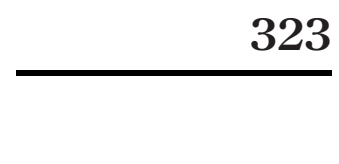

in either the public relations or business communication literature remains scant to date. Notable exceptions are the studies by Kelly et al. (2010) and Laskin (2009) that show how IR is changing from mere financial reporting to a relationship-building activity that requires two-way communication. In line with this changing role of $\mathrm{IR}$, there is an increasing recognition that IR practitioners need to broaden their skills set and be trained in both finance and corporate communications/public relations to meet the demands of the current business environment (Kelly et al., 2010). Empirical evidence on how such cross-training would improve IR quality, however, is missing to date. The current paper builds on the recognized importance of IROs having a skills set that goes beyond financial reporting and provides an empirical study that add support to the theoretical model of the value of expert diversity in the IR function. We find that a diverse educational background has a positive influence on IR quality and also negatively affects the number of shareholder activism incidents that companies are exposed to. In particular, marketing and communication experts can contribute to a richer interaction between shareholders and their companies, which reinforces the theoretical notion that relationship marketing and communication frameworks are important tools for the IR function (Laskin, 2009; Kelly et al., 2010).

Unfortunately, current IR practice often provides a different picture. Descriptive results provided in this paper confirm earlier research, showing that the IR function is often subordinated and controlled by the finance department. Less than a third of the sampled companies employ IROs with a marketing or communication background. Considering that this paper empirically demonstrates the added value of the broader skills set that prior studies called for (Laskin, 2009; Kelly et al., 2010), companies are advised to cross-train their IROs in both finance and marketing/communication. Our results show that this may lead to fewer shareholder activism incidents for these companies.

We conclude by noting that the empirical study at hand is best understood as exploratory research on an underexplored but important topic. Its main limitation 
CCIJ

16,4

324 is the limited sample size, which makes advanced statistical inferences challenging. Further research is advised to try and collect larger samples as well as to internationally generalize our results. Another possible constraint of this study is that by looking only at the educational background of IROs our measure of educational diversity ignores other organizational arrangements, coordination, and ways in which finance specialists could be working together with corporate communication, public relations, and marketing specialists when managing IR. Future research may examine how such other examples of cross-functional collaboration impact IR quality.

\section{References}

ABAF (2010), "ABAF-BVFA: Belgian Association of Financial Analysts", available at: www. abaf.be/index.php (accessed 28 September 2010).

Ackoff, R. (1999), Re-creating the Corporation: A Design of Organizations for the 21st Century, Oxford University Press, New York, NY.

Allen, C.E. (2002), "Building mountains in a flat landscape: investor relations in the post-Enron era”, Corporate Communications: An International Journal, Vol. 7 No. 4, pp. 206-11.

Ancona, D. and Caldwell, D. (1992), "Demography and design: predictors of new product team performance", Organization Science, Vol. 3 No. 3, pp. 321-41.

Armour, J., Deakin, S. and Konzelmann, S. (2003), "Shareholder primacy and the trajectory of UK corporate governance”, British Journal of Industrial Relations, Vol. 41 No. 3, pp. 531-55.

Bantel, K. and Jackson, S. (1989), "Top management and innovations in banking: does the composition of the top team make a difference?", Strategic Management Journal, Vol. 10 No. 1, pp. 107-24.

Becht, M., Franks, J., Mayer, C. and Rossi, S. (2008), "Returns to shareholder activism: evidence from a clinical study of the Hermes UK Focus Fund”, Review of Financial Studies, Vol. 22 No. 8, pp. 3093-129.

Berry, L. (1995), "Relationship marketing of services - growing interest, emerging perspectives", Journal of the Academy of Marketing Science, Vol. 23 No. 4, pp. 236-45.

Black, B. (1998), Shareholder Activism and Corporate Governance in the United States, Macmillan, London.

Boeker, W. (1997), "Strategic change: the influence of managerial characteristics and organizational growth", Academy of Management Journal, Vol. 40 No. 1, pp. 152-70.

Botosan, C. (1997), "Disclosure level and the cost of equity capital", Accounting Review, Vol. 72 No. 3, pp. 323-49.

Brav, A., Jiang, W., Partnoy, F. and Thomas, R. (2008), "Hedge fund activism, corporate governance, and firm performance”, The Journal of Finance, Vol. 63 No. 4, pp. 1729-75.

Bunderson, J. and Sutcliffe, K. (2002), "Comparing alternative conceptualizations of functional diversity in management teams: process and performance effects", Academy of Management Journal, Vol. 45 No. 5, pp. 875-93.

Cohen, W. and Levinthal, D. (1990), “Absorptive capacity: a new perspective on learning and innovation”, Administrative Science Quarterly, Vol. 35 No. 1, pp. 128-52.

Cziraki, P., Renneboog, L. and Szilagyi, P. (2010), "Shareholder activism through proxy proposals: the European perspective”, European Financial Management, Vol. 16 No. 5, pp. 738-77.

Del Guercio, D. and Hawkins, J. (1999), "The motivation and impact of pension fund activism", Journal of Financial Economics, Vol. 52 No. 3, pp. 293-340. 
Del Guercio, D., Seery, L. and Woidtke, T. (2008), "Do boards pay attention when institutional investor activists 'just vote no'?”, Journal of Financial Economics, Vol. 90 No. 1, pp. 84-103.

Dolphin, R. (2004), "The strategic role of investor relations", Corporate Communications: An International Journal, Vol. 9 No. 1, pp. 25-42.

Ellis, C.D. (1985), "How to manage investor relations", Financial Analysts Journal, March/April, pp. 34-41.

Fama, E. (1980), "Agency problems and the theory of the firm”, The Journal of Political Economy, Vol. 88 No. 2, pp. 288-307.

Farraghe, E., Kleiman, R. and Bazaz, M. (1994), "Do investor relations make a difference?", The Quarterly Review of Economics and Finance, Vol. 34 No. 4, pp. 403-12.

Francis, J., Hanna, D. and Philbrick, D. (1998), "Management communications with securities analysts", Journal of Accounting and Economics, Vol. 24, pp. 363-94.

Gelb, D.S. (2000), "Managerial ownership and accounting disclosures: an empirical study", Review of Quantitative Finance and Accounting, Vol. 15, pp. 169-85.

Gibbins, M., Richardson, A. and Waterhouse, J. (1990), "The management of corporate financial disclosure: opportunism, ritualism, policies and processes", Journal of Accounting Research, Vol. 28, pp. 121-43.

Gillan, S. and Starks, L. (2007), "The evolution of shareholder activism in the United States", Journal of Applied Corporate Finance, Vol. 19 No. 1, pp. 55-73.

Gneezy, U. and Potters, J. (1997), "An experiment on risk taking and evaluation periods", Quarterly Journal of Economics, Vol. 112 No. 2, pp. 631-45.

Hambrick, D., Cho, T. and Chen, M. (1996), "The influence of top management team heterogeneity on firms' competitive moves", Administrative Science Quarterly, Vol. 41 No. 4, pp. 659-84.

Healy, P., Hutton, A. and Palepu, K. (1999), "Stock performance and intermediation changes surrounding sustained increases in disclosure", Contemporary Accounting Research, Vol. 16 No. 3, pp. 485-520.

Helm, S. (2007), "The role of corporate reputation in determining investor satisfaction and loyalty", Corporate Reputation Review, Vol. 10 No. 1, pp. 22-37.

Hendry, J., Sanderson, P., Barker, R. and Roberts, J. (2007), "Responsible ownership, shareholder value and the new shareholder activism", Competition and Change, Vol. 11 No. 3, pp. 223-40.

Hirschman, A. (1970), Exit, Voice, and Loyalty: Responses to Decline in Firms, Organizations, and States, Harvard University Press, Cambridge, MA.

Hoffmann, A., Pennings, J. and Wies, S. (2011), "Relationship marketing's role in managing the firm-investor dyad”, Journal of Business Research, Vol. 64 No. 8, pp. 896-903.

Hong, H. and Huang, M. (2005), "Talking up liquidity: insider trading and investor relations", Journal of Financial Intermediation, Vol. 14 No. 1, pp. 1-31.

Hong, Y. and Ki, E.J. (2007), "How do public relations practitioners perceive investor relations? An exploratory study", Corporate Communications: An International Journal, Vol. 12 No. 2, pp. 199-213.

Ikenberry, D. and Lakonishok, J. (1993), "Corporate governance through the proxy contest: evidence and implications”, Journal of Business, Vol. 66 No. 3, pp. 405-35.

Jayne, M. and Dipboye, R. (2004), "Leveraging diversity to improve business performance: research findings and recommendations for organizations", Human Resource Management, Vol. 43 No. 4, pp. 409-24.

\section{Educational diversity}

325 
CCIJ

16,4

326

Jehn, K., Northcraft, G. and Neale, M. (1999), "Why differences make a difference: a field study of diversity, conflict, and performance in workgroups", Administrative Science Quarterly, Vol. 44 No. 4, pp. 741-63.

Jensen, M. and Meckling, W. (1976), “Theory of the firm: managerial behavior, agency costs and ownership structure", Journal of Financial Economics, Vol. 3 No. 4, pp. 305-60.

Karpoff, J. (1999), "The impact of shareholder activism on target companies: a survey of empirical findings", working paper, Washington University Business School, University of Washington, Seattle, WA, 18 August.

Kelly, K.S., Laskin, A.V. and Rosenstein, G.A. (2010), "Investor relations: two-way symmetrical practice”, Journal of Public Relations Research, Vol. 22 No. 2, pp. 182-208.

Kitchen, M. (2000), "The value of honesty", Financial Times, Vol. 8, p. 22.

Klein, A. and Zur, E. (2009), "Entrepreneurial shareholder activism: hedge funds and other private investors", The Journal of Finance, Vol. 64 No. 1, pp. 187-229.

Lang, M. and Lundholm, R. (1996), "Corporate disclosure policy and analyst behavior", Accounting Review, Vol. 71 No. 4, pp. 467-92.

Laskin, A. (2009), “A descriptive account of the investor relations profession”, Journal of Business Communication, Vol. 46 No. 2, p. 208.

Marston, C. (1996), "The organization of the investor relations function by large UK quoted companies", Omega, Vol. 24 No. 4, pp. 477-88.

Morgan, R. and Hunt, S. (1994), "The commitment-trust theory of relationship marketing", The Journal of Marketing, Vol. 58 No. 3, pp. 20-38.

Morrison, R. and Adams, J. (1991), Contemporary Career Development Issues, Lawrence Erlbaum Associates, Hillsdale, NJ.

NIRI (2010), National Investor Relations Institute, available at: www.niri.org/FunctionalMenu/ About.aspx (accessed 28 September 2010).

O'reilly, C. III, Caldwell, D. and Barnett, W. (1989), "Work group demography, social integration, and turnover”, Administrative Science Quarterly, Vol. 34 No. 1, pp. 21-37.

Petersen, B. and Martin, H. (1996), "CEO perceptions of investor relations as a public relations function: an exploratory study", Journal of Public Relations Research, Vol. 8 No. 3, pp. 173-209.

Rao, H. and Sivakumar, K. (1999), "Institutional sources of boundary-spanning structures: the establishment of investor relations departments in the Fortune 500 industrials", Organization Science, Vol. 10 No. 1, pp. 27-42.

Richardson, G. (1972), "The organisation of industry”, The Economic Journal, Vol. 82 No. 327, pp. 883-96.

Ryder, N. and Regester, M. (1988), Investor Relations, Hutchinson Business Books, London.

Savage, H. (1970), “Crucial role of investor relations”, Harvard Business Review, Vol. 48 No. 6, pp. 122-30.

Shefrin, H.M. (2002), Beyond Greed and Fear: Understanding Behavioral Finance and the Psychology of Investing, Oxford University Press, New York, NY.

Smith, M. (1996), "Shareholder activism by institutional investors: evidence from CalPERS", The Journal of Finance, Vol. 51 No. 1, pp. 227-52.

Strickland, D., Wiles, K. and Zenner, M. (1996), "A requiem for the USA: is small shareholder monitoring effective?”, Journal of Financial Economics, Vol. 40 No. 2, pp. 319-38.

Tuominen, P. (1997), "Investor relations: a Nordic school approach", Corporate Communications: An International Journal, Vol. 2 No. 1, pp. 46-55. 
Wallerstein, I. (1974), The Modern World-system: Capitalist Agriculture and the Origins of the European World-economy in the Sixteenth Century, Academic Press, New York, NY.

Whitwell, G.J., Lukas, B.A. and Hill, P. (2007), "Stock analysts' assessments of the shareholder value of intangible assets", Journal of Business Research, Vol. 60 No. 1, pp. 84-90.

Williams, R., Hoffman, J. and Lamont, B. (1995), "The influence of top management team characteristics on M-form implementation”, Journal of Managerial Issues, Vol. 7 No. 4, pp. 466-81.

Wind, Y. (2005), "Marketing as an engine of business growth: a cross-functional perspective", Journal of Business Research, Vol. 58 No. 7, pp. 863-73.

\begin{abstract}
About the authors
Dr Arvid O.I. Hoffmann received his $\mathrm{PhD}$ degree in 2007 from the University of Groningen and currently holds the position of Assistant Professor in Finance at Maastricht University. He is Research Fellow at the Network for Studies on Pensions, Aging and Retirement (Netspar) and at the Meteor Research School of Maastricht University. His research interests lie in the area of the marketing-finance interface, consumer financial decision making, and investor relations. He publishes in leading journals such as the International Journal of Research in Marketing, Journal of Business Research and Journal of the Academy of Marketing Science. Arvid O.I. Hoffmann is the corresponding author and can be contacted at: a.hoffmann@maastrichtuniversity.nl

Aida Tutic received her MSc degree in International Business in 2010 from Maastricht University with a specialization in Marketing-Finance. Her research interests are in investor relations and educational diversity.

Simone Wies received her MSc degree in International Business in 2009 from Maastricht University with a specialization in Marketing-Finance. She currently works as a $\mathrm{PhD}$ candidate in the Department of Finance at Maastricht University. Her research focuses on the marketing-finance interface, in particular on how capital market outcomes influence marketing actions and vice versa. Simone Wies has published her academic work in the Journal of Business Research.
\end{abstract}

\footnotetext{
To purchase reprints of this article please e-mail: reprints@emeraldinsight.com
} Or visit our web site for further details: www.emeraldinsight.com/reprints 